\title{
Identifikasi dan Karakterisasi Isolat Rhizobacteri Osmotoleran dari Merapi
}

DOI 10.18196/pt.2016.054.32-36

\author{
Agung Astuti \\ Program Studi Agroteknologi, Fakultas Pertanian, Universitas Muhammadiyah Yogyakarta, Jl. Lingkar Selatan, Kasihan, Bantul, \\ Yogyakarta 55183; Email: agung_astuti@yahoo.com
}

\begin{abstract}
ABSTRAK
Dalam proses Isolasi Rhizobakteri Merapi didapatkan isolat MA, MB, dan MD yang dapat bertahan dari tekanan osmotik hingga 2,75 M NaCl. Isolat MD lebih baik dalam melarutkan phospat dibandingkan isolat MA dan MB, akan tetapi isolat MA dan MB lebih baik kemampuannya dalam proses nitrifikasi dan amonifikasi dibandingkan dengan isolat MD. Penelitian ini bertujuan untuk mengidentifikasi isolat Rhizobakteri Merapi serta karakterisasinya. Hasil menunjukan bahwa ada perbedaan dalam karakteristik dari ke-empat isolat Rhizobakteri Merapi dimana isolat MB dan MC (putih circular-entire shape), sedangkan isolat MA (curled-white dengan undulate edge), dan isolat MC (ramose-yellow dengan filamentous edge) dan isolat MD mempunyai diameter paling besar $(1.5 \mathrm{~mm})$. Sedangkan dalam karakteristik sel, hampir semua sama yaitu memiliki gram negatif dan bentuk batang, kecuali isolat MD yang berbentuk coccus. Semua isolat menunjukan sifat aerob dan fermentatif, walaupun isolat MD memiliki kemampuan menghidrolisis pati paling kuat. Tipe pertumbuhan dari isolat adalah pertumbuhan cepat yang dapat mencapai fase log pada 48 jam dan jumlah koloni akan turun setelahnya.

Kata Kunci: Rhizobakteri, Identifikasi, Karakterisasi
\end{abstract}

\section{ABSTRACT}

Rhizobacteri Merapi isolates have been detected, and MA, MB, and MD isolates could withstand osmotic stress up to >2.75 M NaCl. MD isolate was stronger in dissolving phospate than MA and MB isolates, but MA and MB isolates had much stronger nitrification capability and could perform ammonification than MD isolate. This research studied about Rhizobacteri Merapi isolates as identification, as well as their characterization. The results show that there is a difference in colonial characteristic of four Rhizobacteri Merapi isolates where MB and MC isolates (white circular-entire shape), except for MA isolate (curled-white with undulate edge) and MC isolate (ramose-yellow with filamentous edge) and also that MD isolate have the largest diameter (1,5 mm). Cell characteristics, however, were the same, gram-negative and were rod shaped, except for MD isolate (coccus). All showed aerob and fermentative characteristics, although MD isolate was able to very strongly hydrolyze starchs. The growth type is fast growing which reach log phase for after 48 hours and then the number of colony decrease.

Keywords: Rhizobacteri, Identification, Characterization

\section{PENDAHULUAN}

Peristiwa erupsi Merapi pada akhir bulan November 2011 di Daerah Istimewa Yogyakarta berdampak pada rusaknya ratusan hektar lahan pertanian. Hampir sebagian besar lahan yang berada di sekitar gunung Merapi terkena material vulkanik yang menyebabkan semua tanaman menjadi mati. Hal ini tentu sangat berpengaruh terhadap perkembangan mikroorganisme yang ada di dalam tanah di sekitar gunung Merapi. Menurut Abdullah (2011) lahar dan awan panas dapat menyebabkan kerusakan ekosistem miroorganisme tanah. Mikroorganisme tanah dapat musnah saat lahan tertutup lava pijar yang sangat panas. Namun ternyata kondisi pasca erupsi Merapi masih menunjukkan adanya sebagian tanaman yang mampu hidup sebagai tanaman pioneer. Hal ini mengindikasikan bahwa tanaman tersebut memiliki kemampuan adaptasi yang luar biasa, antara lain karena adanya dukungan mikrobia di dalam tanah.

Salah satu faktor yang berperan penting 
dalam pertumbuhan sebagian besar tanaman tersebut ialah adanya mikroorganisme dalam tanah yang memiliki kemampuan untuk mengembalikan kesuburan tanah sehingga tanaman masih mampu untuk tumbuh dan berkembang. Salah satu mikrobia dalam tanah yang memiliki kemampuan untuk mengembalikan kesuburan tanah yaitu Rhizobacteri. Mikroorganisme ini sudah terbukti dalam beberapa penelitian memiliki kemampuan untuk meningkatkan bahkan mempertahankan kesuburan tanah. Hasil penelitian Astuti (2012) memperoleh empat isolat dari akar rumput di lahan pasir vulkanik Merapi, yaitu isolat MA, MB dan MD. Isolat tersebut tahan terhadap cekaman osmotik hingga $>2,75 \mathrm{M} \mathrm{NaCl}$, sedang isolat $\mathrm{MC}<0,5$ $\mathrm{M} \mathrm{NaCl}$. Isolat MD lebih kuat kemampuan melarutkan fosfat, dibanding dengan isolat MA dan $\mathrm{MB}$, sedangkan isolat MC sangat rendah. Semua isolat tidak mampu memfiksasi nitrogen, namun isolat MA dan MB kemampuan nitrifikasinya sangat kuat dan mampu melakukan amonifikasi daripada isolat MD dan isolat MC (Astuti dkk, 2013).

Mengingat potensi isolat tersebut untuk dikembangkan sebagai pupuk hayati maka untuk selanjutnya isolat disebut sebagai Rhizobacteri Merapi. Adapun permasalahannya adalah species apakah Rhizobacteri yang ada di lahan pasir vulkanik Merapi. Untuk itu perlu dilakukan karakterisasi baik di tingkat koloni, sel, sifat fisiologis dan kurve pertumbuhannya, sesuai dengan manual pada Bergey's Manual of Determinative Bacteriology. Penelitian ini bertujuan untuk mengidentifikasi dan mengkarakterisasi Rhizobacteri Merapi.

\section{BAHAN DAN METODE}

Bahan

Bahan yang digunakan adalah Rhizobacteri Merapi isolat MA, MB, MC, MD, medium Nutrien Agar, Luria Bertani+ $\mathrm{NaCl}$, medium Pati cair, medium Sukrosa, medium Glukosa.

Alat

Alat yang digunakan adalah untuk Sterilisasi (Autoklaf, oven, Erlemeyer, gelas piala), tahap isolasi dan pemurnian (lampu alkohol, lumpang dan martir, tabung reaksi, jarum ose, petridish, pipet ukur, driglasky, skalpel, pinset, mikro pipet, blue dan yellow tip), alat analisis (Starquad colony counter, timbangan elektrik, mikroskop).

\section{Metode Percobaan}

Penelitian laboratorium dengan melakukan eksperimen yang menggunakan metode deskriptif, meliputi dua tahap yaitu karakterisasi dan penentuan kurve pertumbuhan.

Tahap I adalah Karakterisasi koloni isolat Rhizobacteri Merapi dengan metode surface plating pada medium $\mathrm{LB}+\mathrm{NaCl}$. Karakterisasi sel dengan pengecatan gram dari isolat yang ditumbuhkan pada medium LB. Sifat fermentatif dengan inokulasi pada medium pati cair, sukrosa, glukosa dalam tabung durham. Aerobisitas dengan inokulasi pada medium LB dalam tabung reaksi.

Tahap II adalah penentuan kurve pertumbuhan isolat dengan inokulasi surface plating pada medium $\mathrm{LB}+\mathrm{NaCl}$ dan jumlah mikroba dihitung pada hari ke-0, 1, 2, 3, 4, 5, 6 .

\section{HASIL DAN PEMBAHASAN}

Isolasi dan Pemurnian isolat Rhizobacteri Merapi

Untuk mendapatkan isolat Rhizobacteri Merapi yang murni maka dilakukan pemisahan 
dari lingkungan sekitarnya dengan metode permukaan (surface plating method) dan menumbuhkannya sebagai biakan murni menggunakan metode goresan (streak plating method) (Jutono dkk., 1980). Plating awal yang berasal dari sumber, menghasilkan 8 jenis isolat berbeda berdasarkan bentuk dan warnanya (Astuti, 2010), yang selanjutnya dilakukan replating. Hasil yang diperoleh, terdapat beberapa jenis koloni yang masih sama bentuk, warna dan ukurannya sehingga pada re-plating kedua diperoleh 4 isolat Rhizobacteri Merapi. yang berbeda bentuk, warna, ukurannya, yaitu isolat MA, MB, MC dan MD. Visualisasi isolat pada gambar 1 sedang karakter warna dan diameter koloni pada tabel 1.

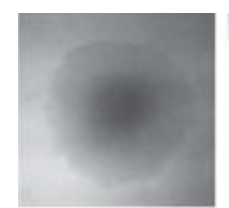

(a) Putih serabut

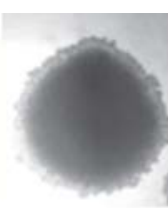

(b) Putih

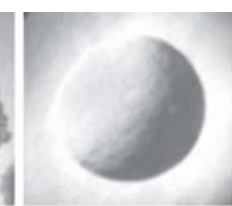

(c) Kuning

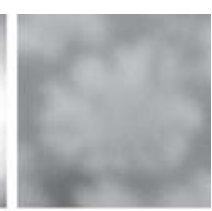

(d) Putih kream
Gambar 1. Koloni isolat Rhizobacteri Merapi MA, MB, MC dan MD

Tabel 1. Warna \& Diameter Koloni Isolat Rhizobacteri Merapi

\begin{tabular}{lllll}
\hline $\begin{array}{l}\text { Karakter } \\
\text { Koloni }\end{array}$ & Isolat MA & Isolat MB & Isolat MC & Isolat MD \\
\hline Warna & Putih serabut & Putih & Kuning & Putih krem \\
diameter & $0,1 \mathrm{~cm}$ & $0,2 \mathrm{~cm}$ & $0,1 \mathrm{~cm}$ & $1,5 \mathrm{~cm}$ \\
\hline
\end{tabular}

\section{Warna koloni isolat Rhizobacteri Merapi} adalah putih-krem dan kuning, dengan diameter koloni berkisar antara 0,1 -0,2 cm, sementara menurut Holt et al. (1994) warna Rhizobacteri adalah putih atau putih kekuningan pada medium DYPG dengan ukuran sel 0,9-1,3 x 2,1-2,5 um.
Mikrobia hasil isolasi yang telah tumbuh sebagai koloni tunggal, selanjutnya dimurnikan dan di-identifikasi menurut karakterisasi bentuk koloni, diameter koloni, elevasi, bentuk tepi, struktur dalam, warna dan karakterisasi bentuk sel serta sifat gram.

\section{Identifikasi Koloni dan Sel Rhizobacteri Merapi}

Determinasi meliputi kegiatan identifikasi dan klasifikasi. Kriteria yang biasanya digunakan dalam mengklasifikasikan bakteri adalah: (1) Karakteristik morfologi meliputi karakterisrik sel vegetatif dan sel reproduktif vegetatif (spora), (2) Karakteristik kultur yaitu pertumbuhan medium cair (aerobisitas) dan medium padat (bentuk koloni, elevasi, bentuk tepi dan struktur dalam), (3) Sifat gram positif atau gram negatif (Pelczar et al, 2001). Hasil karakterisasi koloni dan sel isolat Rhizobacteri Merapi tersaji pada tabel 2.

Tabel 2. Karakterisasi Koloni dan Sel Isolat Rhizobacteri Merapi

\begin{tabular}{lllll}
\hline Karakter Koloni & Isolat MA & Isolat MB & Isolat MC & Isolat MD \\
\hline Bentuk koloni & Curled & Circular & Circular & Ramuse \\
Bentuk tepi & Undulate & Entire & Entire & Filamentous \\
Elevasi & Convex & Law Convex & Law Convex & Convex rugose \\
Struktur dalam & Transparant & Coarsely granular & Filamentous & Arborescent \\
\hline
\end{tabular}

Tabel 3. Karakterisasi Sel Isolat Rhizobacteri Merapi

\begin{tabular}{lllll}
\hline Karakter Koloni & Isolat MA & Isolat MB & Isolat MC & Isolat MD \\
\hline Bentuk sel & Batang & Batang & Batang & Coccus \\
Gram & Negatif & Negatif & Negatif & Negatif \\
\hline
\end{tabular}

Hasil identifikasi diperoleh bentuk koloni isolat Rhizobacteri Merapi adalah Circulair, Curled dan Ramuse, dengan bentuk tepi Entire, 
Undulate, Filamentous. Menurut Holt et al. (1994) secara umum Rhizobacteri berbentuk datar (flat) sampai cembung (convex) dan kerucut (umbonate). Hal ini sesuai dengan koloni isolat Rhizobacteri Merapi yang bentuk elevasinya Convex (lawRugose).

Karakterisasi sel Rhizobacteri Merapi adalah bakteri gram negatif dengan bentuk batang (rods) (Holt et al., 1994). Hal tersebut sesuai dengan sifat gram isolat Rhizobacteri Merapi yaitu gram negatif, dengan bentuk batang dan batang pendek.

\section{Karakterisasi Fisiologi Isolat Rhizobacteri Merapi}

Karakteristik fisiologi dilakukan dengan pengujian biokimia seperti penggunaan senyawa karbon sebagai fermentatif dan pengujian biokimia khusus lainnya (Pelczar et al, 2001). Hasil pengujian sifat fisiologi isolat Rhizobacteri Merapi pada tabel 4.

Tabel 4. Sifat fisiologi isolat Rhizobacteri Merapi

\begin{tabular}{llllll}
\hline Penguijan & & MA & MB & MC & MD \\
Aerobisitas & & Aerob & Aerob & Aerob & Aerob \\
\hline \multirow{2}{*}{ Sukrosa } & Asam & $3+$ & $1+$ & $2+$ & $1+$ \\
& Gas & $1+$ & $1+$ & $1+$ & $1+$ \\
Glukosa & Asam & $2+$ & $1+$ & $1+$ & $2+$ \\
\multirow{2}{*}{ Amilum } & Gas & $1+$ & $1+$ & $1+$ & $1+$ \\
\hline
\end{tabular}

Sifat fisiologi dari empat isolat Rhizobacteri Merapi semua bersifat aerob yang ditunjukkan dengan adanya pertumbuhan di permukaan medium LBC pada tabung reaksi. Hal tersebut sesuai dengan sifat Rhizobacteri pada Bergey's Manual of Determinative Bacteriology (Holt et al., 1994) yaitu menghasilkan asam dari glukosa dan menghidrolisis pati, tampak bahwa isolat MA bersifat sangat kuat.

\section{Kurve Pertumbuhan isolat Rhizobacteri Merapi}

Optimasi inokulum dilakukan untuk mengetahui tipe pertumbuhan isolat dan mengoptimalkan jumlah bakteri Rhizobacteri Merapi pada inokulum yang akan direinokulasikan pada tanaman agar jumlah Rhizobacteri Merapi dapat mencukupi dalam menginfeksi akar yang optimal. Syarat untuk dapat menghasilkan inokulum yang optimal untuk Rhizobacteri adalah $10^{8}-10^{9} \mathrm{CFU} / \mathrm{ml}$ (Elkan, 1987). Untuk mencapai jumlah sel yang memenuhi maka dilakukan kultur gojog selama 144 jam dan dilakukan perhitungan jumlah sel dengan metode plating setiap 24 jam. Rerata jumlah sel dari 4 isolat dapat dilihat pada gambar 2 .

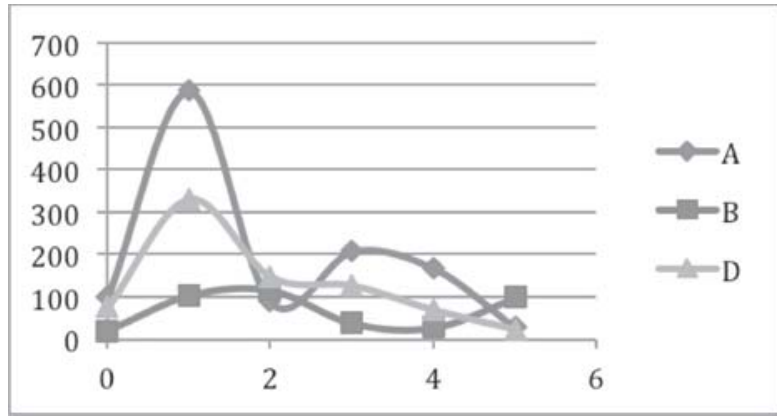

Gambar 2. Pertumbuhan Isolat Rhizobacteri Merapi (x $\left.10^{7} \mathrm{cfu} / \mathrm{ml}\right)$

Keterangan : $A(M A), B$ (isolat MB), D (isolat MD)

Dari gambar 2 dapat dilihat bahwa pada kultur gojog 48 jam pertumbuhan isolat bakteri Rhizobacteri Merapi sudah optimal. Pada masa tersebut bakteri dalam fase akhir log yaitu pertumbuhan dengan peningkatan secara eksponensial berlangsung sangat cepat, meskipun setiap isolat berbeda - beda, diduga dipengaruhi oleh tipe pertumbuhan masing masing isolat, sedang pertumbuhan isolat 
bakteri Rhizobacteri Merapi baru mulai fase penurunan setelah 48 jam dan jumlah bakteri terus menurun sampai waktu 72 jam.

\section{SIMPULAN}

Karakteristik koloni dari empat isolat Rhizobacteri Merapi ada perbedaan yaitu isolat $\mathrm{MB}$ dan $\mathrm{MC}$ berbentuk koloni circular-entire dan berwarna putih kecuali isolat MA (curled-putih dengan tepi undulate) dan isolat MC (ramosekuning dengan tepi filamentous) serta diameter koloni isolat MD paling besar $(1,5 \mathrm{~mm})$. Sementara karakteristik selnya mempunyai kesamaan sifat gram (negatif) dan bentuk (batang) kecuali isolat MD (Coccus). Sifat fisiologi dari empat isolat Rhizobacteri Merapi semua bersifat aerob dan fermentatif, namun isolat MD sangat kuat karena dapat menghidrolisis pati. Kurve pertumbuhan dari empat isolat Rhizobacteri Merapi mencapai fase log sampai 48 jam kemudian terjadi penurunan koloni. Mengingat ke empat isolat Rhizobacteri Merapi banyak persamaannya, namun mempunyai perbedaan yang besar dalam fungsi sebagai pupuk hayati maka perlu dilakukan identifikasi sampai tingkat molekular melalui amplifikasi PCR dan analisis 16sDNA Sequencing.

\section{UCAPAN TERIMA KASIH}

Kepada Direktorat Jenderal Pendidikan Tinggi untuk dana penelitian Hibah Bersaing tahun 2013.

\section{DAFTAR PUSTAKA}

Abdullah Abas Idjudin, Dedy Erfandi dan S, Sutono. 2011. Teknologi Peningkatan Produktivitas Lahan Endapan Vulkanik Pasca Erupsi G. Merapi. http://balittanah.litbang.deptan,go,id/ dokumentasi/lainnya/Teknologi\%20Peningkatan\%20Prod\%20Lhn\%20Endpn\%2OVolk\%2OPasca\%20Erupsi\%20G\%20Merapi\%20_Pa\%20Abas.pdf. Akses 23 Maret Agung_Astuti. 2012. Isolasi Rhizobacteri Lahan Pasir Vulkanik
Merapi Yang Tahan Terhadap Cekaman Kekeringan. Disampaikan pada seminar ilmiah di Fakultas Pertanian UMY pada 24 Nopember 2012

Agung_Astuti, Sarjiyah dan Hariyono. 2013. Uji Potensi Rhizobacteri Lahan Pasir Vulkanik Merapi Untuk Dikembangkan Sebagai Pupuk Hayati Di Lahan Marginal, Dalam Prosiding Seminar Nasional Pemanfaatan Lahan Marginal Sumberdaya Lokal untuk Mendukung Ketahanan Pangan Lokal, HITI \& UNSOED Purwokerto, 8 Juni 2013.

Brock, 1997. Biology of Microorganisms. Southern Illinois University-carbondale. Prentice Hall International, Inc. Elkan, 1987. Determinative Bacteria : Bergey's Manual. Hartmann, A., Prabhu, S.R., and Galinski, E.A. 1991. Osmotolerance of diazotrophic rhizosphere bacteria. Plant and Soil 137:105109.

Pelczar, M.J dan E.C.S. Chan. 1988. Dasar - dasar Mikrobiologi. Penerbit Universitas Indonesia. Jakarta.

Sutariati, G.A.K dan A. Wahab. 2006. Isolasi dan Uji Kemampuan Rizobacteri Indigenous sebagai agensia Pengendali hayati penyakit pada tanaman cabai. Fakultas Pertanian Universitas Haluoleo dan Tridharma Anduonohu, Kemdari, Sulawesi tenggara. http://hortikukltura/ litbang.deptan,go,id/jurnal_pdf/ 201/sutartiati.cabai.pdf. Akses 15 Maret 2011

Thakuria, D., N.C. Talukdar, C. Goswami, S. Hazarika, R.C. Boro, M.R. Khan. 2004. Characterization And Screening Of Bacteria From Rhizosphere Of Rice Grown In Acidic Soil Of Assam. Current Sci86: 978-985

Thuar, A.M., C.A. Olmedo. C. Bellone.2004. Green House Studies On Growth Promotion Of Maize Inoculated With Plant Growth Promoting Rhizobacteria (PGPR). http://www.ag.auburn.edu/ argentina/pdfmanuscripts/thuar.pdf. Akses 23 Maret 2011 Wei, G., J.W. Kloepper, S, S. Tuzun. 1996. Induced Of Systemic Resistance To Cucumber Diseases And Increased Plant Growth Promoting Rhizobacteria Under Field conditions. Phytopathol 86:221-224 